\title{
Grammar Teaching in the Turkish Language Course Curriculum: An Examination in the Context of Acquisitions, Activity, and Teachers' Opinions
}

\author{
Hülya Kodan ${ }^{1, *}$ \& Kürşad Kara ${ }^{1}$ \\ ${ }^{1}$ Bayburt University, Turkey \\ *Corresponding author: Bayburt University, Turkey. E-mail: hulya.kodan@gmail.com
}

Received: February 15, 2021

Accepted: April 5, 2021 Online Published: May 18, 2021

doi:10.5430/jct.v10n2p28

URL: https://doi.org/10.5430/jct.v10n2p28

\begin{abstract}
This research aimed to reveal teachers' opinions about how the grammar-teaching process is related to the acquisitions in the curriculum, activities, and acquisitions presented in the textbooks teaching in mother tongue, the study reviewed different textbooks from four publishers, Cem, Sonuç, Koza, and Ministry of National Education (MEB) publications prepared for the 2018 primary school Turkish language course curriculum and Education Information Network (EBA) of the Turkish Ministry of Education. Moreover, opinions of ten primary school teachers who have taught all grades regarding the teaching process for grammar acquisition were investigated. The study conducted a case study method, which is one of the qualitative research techniques. Besides, a document analysis was conducted to obtain the research findings. Structured interview protocol and document review were used as the data collection tool. The findings of the study revealed that acquisition in the learning areas of reading and writing for grammar in the curriculum was not clearly and transparently identified, and the limits of the teaching framework were not specified. The study findings also revealed that information was transferred only in the majority of the grammar activities in the textbooks. Also, classroom teachers reported that they used different methods on the subjects they could embody in the teaching process, but they claimed to have difficulties in teaching abstract concepts.
\end{abstract}

Keywords: activity, grammar, teacher views, 2018 Primary school Turkish language curriculum

\section{Introduction}

Mother tongue education is considered one of the state's national duties. Language, which is the carrier of material and spiritual culture, should be transferred to future generations in the most appropriate way. Nations, therefore, should teach their mother tongue systematically in formal education institutions. The mother tongue, which also ensures the permanence of the nation, must also be protected by the state. For this purpose, all the individuals who make up a nation must know how to use their mother tongue adequately and effectively. Grammar is important for effective and correct language teaching.

Different approaches are used worldwide to teach grammar. Three of these are the behavioral approach, the cognitive approach, and the constructivist approach. The first, which handles grammar teaching from a behaviorist approach, suggests employing repetition in grammar teaching to reinforce students' positive behaviors and to create habits. Skinner is the leading representative for this theory. The second approach is the cognitive language approach, for which Chomsky is the most important representative. In this approach, students should first develop their understanding skills and then develop their narrative skills (Akyol \& Şahin, 2019). Learning is seen as mental development, not just a change in observable behaviors (Tusting \& Barton, 2011). The third approach is the constructivist approach, according to which the main focus in grammar teaching is to understand and make sense. In the constructivist approach, knowledge is like a network of relationships, students actively make sense of their experiences and their environment (Can, 2009). Finally, according to this approach, grammar teaching should not contain rigid rules, but should be useful and functional (Bentolila, 2006; as cited in Güneş, 2013). Language teaching in line with these approaches is reflected in the curriculum to be applied in schools.

The curriculum aims to improve the expressive and receptive language skills of students in their daily lives and 
encourage them to use their language correctly and properly by teaching the mother tongue (Yaman \& Demirtaş, 2013). Preserving, improving, and benefiting from the mother tongue can only be possible through knowing all the characteristics of the language and using it with all its subtleties (Demir \& Yapıc1, 2007). It is therefore vital to teach the mother tongue with all its subtleties and rules and the educators should know how to do it. This sensitivity brings up the concept of grammar, including all the rules of a language. According to Korkmaz (1992), grammar is a science that examines a language in terms of meaning relationships between sound, form, sentence structure, and various elements of a language, revealing its rules and operational characteristics. Grammar also deals with a language's methods of expression and it outlines the general and special rules of a language and their relationship with each other. Addressing these elements ensures the correct use and learning of a language (Özbay, 2006a). For individuals to understand and use their mother tongue correctly and effectively, they must learn the language rules and avoid making language mistakes. Individuals' need for grammar education emerges here. As Aytaş and Çecen (2010) emphasized that grammar rules are a cornerstone of using the mother tongue correctly.

Without grammar, it is not possible to achieve the desired success in language skill teaching because structural and semantic connections in the language, semantic groupings among words, and links among language indicators occur through grammar (Erdem \& Başaran, 2010). Also, Göğüş (1978) reported that grammar teaching aims to teach language skills and is considered one of the goals of mother tongue education. When the writing skills of an individual who can learn and apply the grammar rules of their mother tongue develops, they can communicate better with other individuals and learn another language much more easily. Thus, individuals' language mistakes are minimized and grammar teaching contributes positively to mental development (Ünal \& Şahinci, 2011). In addition, the requirement to have basic language skills that require compliance with grammar rules places grammar teaching in a central position (Aytaş \& Çeçen, 2010) because grammar is required for comprehension and expression skills. Grammar instruction begins with teaching reading and writing (Güneş, 2013).

The common concept found in definitions of grammar and grammar teaching is the existence of language-related rules. This then raises the question of how to teach these rules or language-related information. Indeed, even this question implies indirect acceptance that language rules should be taught. Knowledge of the rules of a language should somehow be taught. Studies examining the teaching of Turkish grammar have revealed a dominant belief that that grammar should not be taught using traditional methods. Grammar teaching should be performed through intuition, without memorization, by keeping definitions in the background (Güneş, 2007; Erdem, 2007; Kavcar et al.; 1997, Dolunay, 2009). Grammar teaching should not be considered separate from reading, listening, speaking and writing teaching (Göğüş, 1978; Demir \& Yapıc1, 2007; Özbay, 2006a; İşcan \& Kolukısa, 2005; Ünalan, 2006; Yıldız, 2003; Öz, 2001) and it should be applied in a practical way and should not be taught with traditional methods (Güven, 2013; Sever, 2000). Individuals should not be overloaded with information (Demirel, 2000; Erdem, 2008). Grammar rules should be taught free from abstraction (Cemiloğlu, 2004; Schulze, 1998; İşcan \& Kolukısa, 2005) and different methods and approaches should be used (Aydın, 1999; Erdem, 2008; Öz, 2006). Although providing information under different subjects in language teaching is avoided in Turkey's mother tongue curriculum, it has been observed that other countries perform grammar education more explicitly by providing grammatical information in their mother tongue teaching curriculum. For instance, Finland and Hungary were found to include grammar as a separate course in their curricula. Concepts such as grammar and language use are included in the mother tongue education curricula in Spain, Sweden, Korea, Egypt, and Greece (Yaman \& Demirtaş, 2013). Another important finding is in the information provided in the 2004-2005 German language teaching curriculum: First and second graders comprehend the functions of nouns; singular and plural forms; the functions and properties of verbs, adjectives, and pronouns; morphology; word structure; syllabication; word groups; can recognize and combine compound words; and can comprehend the functions and characteristics of prepositions. Besides, topics such as distinguishing nouns; determining verb structures, different tenses, personal pronouns, prefixes, and suffixes; and creating new words are included in the third and fourth grade curricula (Kantaş, 2013).

In the basic educational curriculum in the Czech Republic for Czech language and literature, third-grade students are expected to distinguish between short and long sounds, particularly to compare synonyms, antonyms and homonyms, determine the connections between the text and words; distinguish their basic forms and vocabulary; use nouns, adjectives, and verbs correctly according to grammar rules while speaking; create basic compound and complex sentences from clauses using appropriate conjunctions and other junction words; understand the thoughts of the speaker and the grammatical elements or sounds used in a text; distinguish the sentence types; etc. (Aydın, 2013). As can be seen, grammar rules are expressed clearly in the language teaching curricula of several countries, where there is no hesitation to provide information about the language. These study findings suggest that teaching grammar without providing this type of information can lead to problems. 
In line with the studies examined in this study, the common opinion about grammar and grammar teaching is as follows: The grasp of grammar is necessary for the accuracy of speaking, writing, and reading skills. The basic criteria for being able to detect what is right and what is wrong in the four basic skills (reading, listening, speaking and writing), especially in writing and speaking, are realized through grammar teaching. Therefore, it is not possible to teach the mother tongue while avoiding grammar knowledge. Several researchers studying grammar (Cemiloğlu, 2001; Sinanoğlu, 1958; Demir \& Yapıcı, 2007; Sever, 2000; Güven, 2013; Demirel, 2000) have suggested how grammar should be taught correctly. The common element in their suggestions is to understand grammar as it is taught alongside the four basic Turkish skills, rather than in independent grammar teaching, and the language rules should be taught through an appropriate method.

Reviewing the 2018 Turkish course curriculum in light of this information, the following features can be highlighted: First, a framework is drawn by the curriculum for individuals to make them to think critically, have communication skills, do not only transfer information, and direct the use of metacognitive skills. To be competent in one's mother tongue is to express and interpret concepts, thoughts, opinions, feelings, and facts both verbally and in writing (listening, speaking, reading, and writing). Language competence has been defined as linguistically and creatively engaging in all social and cultural contexts. Grammar teaching conducted by avoiding knowledge is the dominant understanding reflected in the curriculum.

This study aims to examine grammar acquisitions in the primary school Turkish language curriculum within the framework of teacher opinions and activities in the textbooks. In line with this general purpose, the research questions of this study are as follows:

1. How are the grammar acquisitions in the primary school Turkish language curriculum included in terms of learning areas and grade level?

2. How is the reflected level of the grammar acquisitions in the primary school Turkish language curriculum in the activities in the Turkish textbooks?

3. How do primary school teachers perform the teaching process regarding grammar acquisition in the primary school Turkish language curriculum?

\section{Method}

This section presents information about the study design, study group, data collection, data analysis, and study validity and reliability.

\subsection{Study Design}

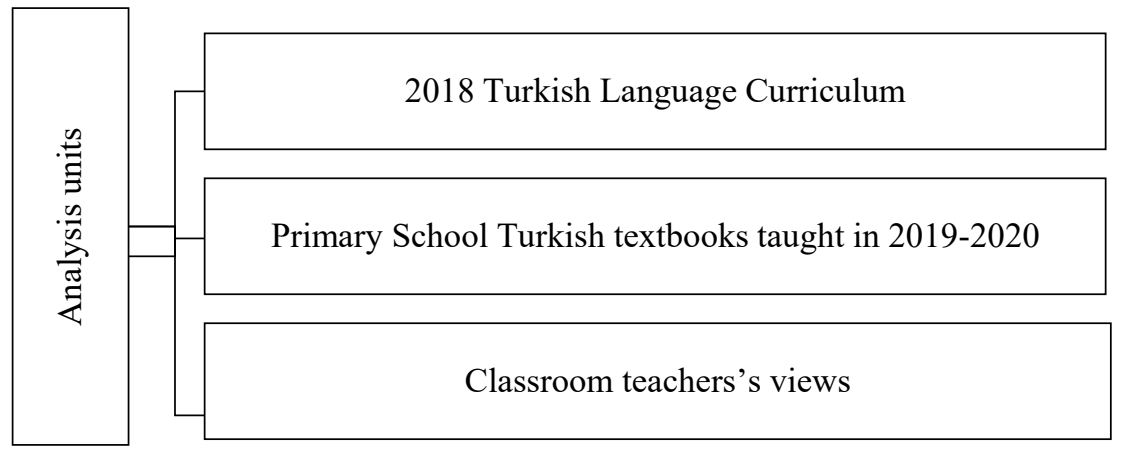

Figure 1. The Units of Analysis Used in Determining the Situation Regarding Grammar Teaching

This study, which aims to address grammar teaching in the context of mother tongue teaching in terms of the acquisition in a program, activities offered in textbooks, and teachers' views on the teaching process, was designed following a case study model, a qualitative research approach. A case study is defined as an intensive and detailed description and analysis of one or more situations (Christensen et al., 2015; Merriam, 2018; Yıldırım \& Şimşek, 2018). 
A case study does not aim to draw general conclusions, unlike other types of research. Its main purpose is to discover the situation, person or phenomenon in its original environment, and to describe and interpret it in detail (Seggie \& Bayyurt, 2017). In this study, the units of analysis were determined as the primary school Turkish lesson curriculum, primary school textbooks, and classroom teachers' views. Because this study attempts to explain a single case with different units of analysis, a holistic multi-case design was used. This design makes it possible to compare different situations.

\subsection{Study Group}

In this study, the units of analysis were determined as a primary school Turkish language curriculum, primary school textbooks, and classroom teachers' views. For the document-based units of analysis, the documents were 2018 Turkish language curriculum and in Education Information Network (EBA) located elementary school textbooks. Elementary school textbooks published by Cem, Sonuç, Koza, and Meb Publications. The documents were chosen as the unit of analysis to reveal how grammar acquisitions are included according to educational fields, class levels.

The other unit of analysis in the study was primary school teachers' views. To gather in-depth information in case studies, information collected from a group instead of all participants can be included in the study (Büyüköztürk et al., 2012, p. 251). Research participants were chosen using purposeful and snowball sampling. When using purposeful sampling, researchers determine the characteristics of the people who will form the research sample (Christensen et al., 2015). In this study, participants consisted of teachers who had taught all grade levels (1st, 2nd, 3rd, and 4th grade) at least once. When using snowball sampling to determine the sample, each participant is asked to suggest other individuals who can participate in the study and meet certain characteristics (Christensen et al., 2015). For the snowball sampling, the participants were asked if they knew people who met the participation requirements. The research was conducted on 10 participants.

The stages of a case study can fall under eight headings:

- Developing research questions

Figure 2. Case Study Stages (Yıldırım \& Şimşek, 2018)

The eight-step path shown in Figure 2 should be followed when conducting a case study. An explanation of the stages is given in detail in the methods part of the research.

\subsection{Data Collection}

In the study, structured interviews and document analysis were used as the data collection methods. Combining data collection methods both increases the validity and reliability of the research and provides a wider perspective on the research results by enriching the research database (Yıldırım \& Şimşek, 2018). In this context, to enrich the research database, the 2018 primary school Turkish course curriculum, which is still in effect, and the primary school Turkish textbooks, published by four different publishing houses and distributed free of charge by the Ministry of National Education to schools were examined. The structured interview form was used. It was prepared by the researchers for the participants.

The researchers prepared questions to reveal how participating primary school teachers directed the teaching process 
concerning grammar acquisition. The questions prepared by the second author of the study were discussed with the first author, and the opinions of two academician experts in classroom education were obtained. In line with these opinions, the questions were rearranged and the interview form was finalized.

\subsection{Data Analysis}

Descriptive analysis and content analysis were used to analyze the data. In the first part of the study, the researchers examined the primary school Turkish lesson curriculum outcomes, and determined the grammar topics and concepts included in the outcomes. In the examination of the textbooks, the researchers evaluated how the topics and concepts of grammar acquisition were presented. In the second part of the study, as a result of the interviews with the primary school teacher, the researchers examined the teachers' opinions and created categories related to the concepts and topics discussed. The guidance of the teachers in the grammar teaching process was expressed according to the outcomes. To increase the validity of the study, the researchers used direct quotations from the teachers. In the descriptive analysis, the teachers were coded from T1 to T10.

\subsection{Validity and Reliability of the Study}

Data diversity was used to ensure the internal validity of the research. In the study, the researchers aimed to explain, in detail, the acquisitions in the primary school Turkish lesson program, activities in the textbooks for the outcomes, and the ways in which primary school teachers direct their teaching processes regarding the outcomes with the variation in the data collection method. In addition, the researchers also used expert opinions on the form of the structured interview, one of the data collection methods. To strengthen the validity of the study, direct quotations reflecting the opinions of the participants were used. In addition, the validity and reliability of the study are strengthened by explaining the process in detail.

\section{Study Findings}

3.1 Findings on the First Sub-Problem

The findings on the first sub-problem of the research are presented in Table 1.

Table 1. Distribution of Grammar Acquisitions in the Primary School Turkish Language Curriculum by Learning Area

\begin{tabular}{cccc}
\hline Grade & \multicolumn{2}{c}{ Learning area } & Sum \\
\cline { 2 - 4 } & $\begin{array}{c}\text { Number of grammar acquisitions } \\
\text { in the field of reading }\end{array}$ & $\begin{array}{c}\text { Number of grammar acquisitions in } \\
\text { the field of writing }\end{array}$ \\
\hline 1 & 3 & 3 & 6 \\
2 & 4 & 3 & 7 \\
3 & 5 & 3 & 8 \\
4 & 6 & 6 & 12 \\
\hline
\end{tabular}

Table 1 compares grammar acquisitions in the Turkish language curriculum according to grade levels. According to the data, grammar acquisitions in the curriculum are considered in the areas of reading and writing, but they are mostly presented, respectively in the fourth, third, second, and first grade. This shows that as the grade level increases, so does students' grammar acquisition. This finding is parallel with the aim of structuring the acquisition of grammar and spelling rules progressively and gradually, as presented in the general purpose of the program, considering the developmental characteristics of the students.

The findings on grammar acquisition, including on grammatical terms in the curriculum, revealed that there is a "fluent reading" title in the Reading learning area and various grammatical acquisitions in the Writing learning area at all grade levels, whereas the acquisitions under the "vocabulary" title in the learning area of Reading are also included in the other learning levels, except in the first grade. The findings also revealed that the common points of the acquisitions were linguistic stress, attention to intonation and pronunciation, and the use of punctuation marks.

Since punctuation marks are a concrete subject, they were more heavily included in the curriculum (MEB, 2018). However, punctuation marks are tightly linked to grammatical rules. When teaching a punctuation mark, the following concepts should be considered: sentences, word groups with a similar meaning, coordinate sentences, incomplete sentences, interrogative sentences, items that should be emphasized in the sentence, reduplication, syllables, conjunctions, addressal, exclamations, proper names, derivational affixes, inflectional suffixes, etc. (Imla K1lavuzu, 
2000). These grammatical structures are not included in the curriculum. No approach is mentioned for how to teach punctuation marks. Below is an analysis of an example in the curriculum in the context of punctuation marks.

In the first reading and writing task, the term "proper noun" was used primarily in the following statement: "The apostrophe should only be used in possessive forms of a proper name." The answer to the question "What is a proper noun?" is informative. We must ensure that students learn this by implicating it. In the second task, the students are taught that a proper name sometimes gets a derivational affix and sometimes gets an inflectional suffix. Will the students be informed that a derivational affix is not separated with an apostrophe, or will it be implicated? (No term like "implicating" is used in the curriculum.) How long does this process take?

The same situation is observed in reading acquisition when paying attention to stress, intonation, and pronunciation. Being able to stress words correctly in Turkish requires knowing more than one grammatical concept: syllables, words, word types, negators, verbs, vowels, consonants, etc. (Işcan, 2015). The correct stress, intonation, and pronunciation are performed in light of this information.

For these two acquisitions, no level distinction was made for the grades.

Table 2. Distribution of Grammar Acquisition by Grade Level

\begin{tabular}{|c|c|c|c|c|}
\hline Acquisition & $\begin{array}{l}\text { First } \\
\text { grade }\end{array}$ & $\begin{array}{l}\text { Second } \\
\text { grade }\end{array}$ & $\begin{array}{l}\text { Third } \\
\text { grade }\end{array}$ & $\begin{array}{c}\text { Fourth } \\
\text { grade }\end{array}$ \\
\hline Using words according to their meanings & $\mathrm{x}$ & $\mathrm{x}$ & $\mathrm{x}$ & $\mathrm{x}$ \\
\hline Reading by paying attention to punctuation marks & $\mathrm{x}$ & $\mathrm{x}$ & $\mathrm{x}$ & $\mathrm{x}$ \\
\hline Reading by paying attention to stress, intonation, and pronunciation & $\mathrm{x}$ & $\mathrm{x}$ & $\mathrm{x}$ & $\mathrm{x}$ \\
\hline Guessing/finding the opposite meanings of words & $\mathrm{x}$ & $\mathrm{x}$ & $\mathrm{x}$ & $\mathrm{x}$ \\
\hline Writing meaningful and grammatical sentences & $\mathrm{x}$ & $\mathrm{x}$ & & \\
\hline Using capital letters and punctuation properly in the correct places & $\mathrm{x}$ & $\mathrm{x}$ & $\mathrm{x}$ & $\mathrm{x}$ \\
\hline Reviewing/editing one's writing & $\mathrm{x}$ & $\mathrm{x}$ & $\mathrm{x}$ & $\mathrm{x}$ \\
\hline Writing the interrogative particle according to the rules & & $\mathrm{x}$ & & \\
\hline Finding synonyms of words & & & $\mathrm{x}$ & $\mathrm{x}$ \\
\hline Using/Distinguishing the meanings of homonyms & & & $\mathrm{x}$ & $\mathrm{x}$ \\
\hline Using homonyms according to their meanings in one's writing & & & $\mathrm{x}$ & \\
\hline $\begin{array}{l}\text { Determining the literal meaning, figurative meaning, and term meaning } \\
\text { of words in the text one reads }\end{array}$ & & & & $\mathrm{x}$ \\
\hline Using conjunctions according to the rules in one's writing & & & & $\mathrm{x}$ \\
\hline $\begin{array}{l}\text { Using words in one's writing with literal meaning, figurative meaning, } \\
\text { and term meaning }\end{array}$ & & & & $\mathrm{x}$ \\
\hline Writing intensified words correctly & & & & $\mathrm{x}$ \\
\hline
\end{tabular}

Table 3. The 38 Grammatical Concepts to Which the Grammatical Topics of Acquisition in the Curriculum are Related

\begin{tabular}{llll}
\hline \multicolumn{2}{c}{ The 38 Grammatical Concepts to Which the Grammatical Topics of Acquisition in the Curriculum are Related } \\
\hline $\begin{array}{l}\text { affixes and suffixes } \\
\text { common nouns } \\
\text { digression }\end{array}$ & $\begin{array}{l}\text { ambiguity } \\
\text { complex sentences } \\
\text { elliptical clauses }\end{array}$ & $\begin{array}{l}\text { antonyms } \\
\text { compound words } \\
\text { figurative meaning }\end{array}$ & $\begin{array}{l}\text { case suffixes } \\
\text { coordinate sentences } \\
\text { grammatical and } \\
\text { ungrammatical sentences }\end{array}$ \\
homonyms & $\begin{array}{l}\text { inflectional suffixes and } \\
\text { derivational affixes } \\
\text { phonetics }\end{array}$ & -ki and -de suffixes & lines \\
parenthetical sentences \\
$\begin{array}{l}\text { proper nouns } \\
\text { syllables }\end{array}$
\end{tabular}


Although grade-based acquisitions are limited, there are several grammatical concepts related to these acquisitions. The main misconception is that providing the students with fewer acquisitions is appropriate for lower student levels just because there are fewer to learn. However, multiple grammatical structures must be taught first before teaching each acquisition. For example, there are eight grammar acquisitions for second graders. If we consider the acquisition of "writing meaningful and grammatical sentences," will the student be informed about grammatical concepts like what a sentence is, that a grammatical sentence is a sentence whose verb is at the end of the sentence, what a verb is, that a sentence is an inverted sentence if the verb is not at the end, and that it is an elliptical clause if there is no verb? How and through which method or approach will students learn about meaningful, grammatical sentences without having these structures explained to them?

For example, the statement "students are encouraged to check what they write for grammar and ambiguity" appears in the article on the acquisition of "T.4.4.11. Organizes what s/he writes" in the fourth-grade curriculum. Not presenting a statement about ambiguity in the acquisitions of earlier grade levels is likely because the acquisition would not be understood. The Writing learning area of all grade levels in the curriculum indicates that first-grade students are asked to examine their writing in terms of incomplete spelling, letters/syllables, and punctuation rules. In addition to these items, awareness should be raised concerning how the acquisitions (finding and distinguishing homonyms, synonyms, and antonyms) are expressed to ensure the proper and appropriate use of the appropriate word in the areas of speaking, listening, and reading. In this context, the absence of an explanation of which dimension of the ambiguity will be handled in the acquisition process shows that the acquisition cannot be expressed clearly. It is anticipated that this may negatively affect the learning and teaching process.

A similar situation has been observed in a second-grade acquisition: 'T.2.4.13. In the acquisition of writing the interrogative particle, according to the rule, there is no information about the rules for teaching how to write the interrogative particle, how to determine the teaching framework.' In the curriculum, the principle of progression according to grade level was not considered in this acquisition. In another acquisition, "T.4.4.18. In the explanation regarding the acquisition of using conjunctions, according to the rules in his/her writings," it is stated that "they are provided to write 'de' and 'ki' conjunctions correctly." It is also not explicitly stated which rules to teach about the use of conjunctions. These uncertainties will likely cause problems in the teaching and training process.

\subsection{Findings on the Second Sub-Problem}

The second research question is: What is the reflected level of the grammar acquisitions in the primary school Turkish language curriculum in the activities in the Turkish textbooks? The findings related to this sub-problem are presented in Table 3.

The textbooks of four publishers in the EBA were examined in terms of the activities included in primary school Turkish textbooks. According to ethical rules, the books belonging to publishers were coded as P1, P2, P3, and P4. Information about the activities in the textbooks is presented in the table below.

Table 4. Information Related to the Activities in the Textbooks

\begin{tabular}{lcccccccc}
\hline Number of activities by publishers & \multicolumn{2}{c}{ First grade } & \multicolumn{2}{c}{ Second grade } & \multicolumn{2}{c}{ Third grade } & \multicolumn{2}{c}{ Fourth grade } \\
\cline { 2 - 9 } & P4 & P3 & P2 & P3 & P1 & P3 & P2 & P3 \\
\hline Total number of events & 119 & 120 & 225 & - & 261 & 258 & 225 & 323 \\
Number of activities for grammar acquisitions & 20 & 24 & 37 & - & 22 & 50 & 25 & 37 \\
Number of grammar activities & - & 1 & 8 & - & - & 12 & 14 & 12 \\
\hline
\end{tabular}

The findings presented in Table 4 reveal that individual publishers' textbooks were examined because no P3 books were exclusively for the second grade. The researchers determined all the activities in the textbooks and evaluated the activities related to grammar acquisition. Activities directly including definitions for grammar acquisition were also exemplified. Table 4 reveals that as grade level increases, the number of activities, including definitions related to grammar, also increases. Definitions transferring information directly were found to be included in all grade levels. Definitions of Turkish Language Association regarding punctuation marks were included in the activities of the P3 textbooks related to the acquisition item on "using capital letters and punctuation marks in appropriate places" at third grade level. The instruction appeared as follows: "common functions of a full stop, comma, colon, exclamation, quotation and question marks, a hyphen, speech line, and apostrophe are emphasized." Therefore, for this activity, grammar is lifted from the context and taught directly. For example, in an activity on the use of hyphens in P3's first-grade textbook, a sample was presented with the following expression: "I used a hyphen (-) when separating 
words when words did not fit at the end of the line." According to the spelling rules of the Turkish Language Association, "When separating the words at the end of the line, a hyphen is used." This rule is included in the first article on the hyphen (Imla Kilavuzu, 2000).

In the activity on the use of the interrogation mark in the second'grade textbook by P2, information about the use of the interrogative particle was transmitted directly: “. . 'mi' is an interrogative particle. This particle can also be used as "mi", "mu", and "mü' formats to match with the word. The interrogative particle is written separately from the word preceding it. However, it is written tied with the suffixes added."

In the third-grade textbook of P3, direct information about how to place a colon correctly in a sentence appeared in the activity as follows: (1) It is used when an example is given after it. (2) It is used when an explanation is given after it. (3) It is used before direct quotations.

In the activity in the fourth-grade P2 textbook, items with information about the use of parentheses were used: (1) The suffix of a proper or common noun is written before the parenthesis. (2) In place of words and elements that are excluded at the beginning, middle, and end of a quotation, an ellipsis can be enclosed in parentheses. (3) After the numbers and letters showing items in writing, closed parentheses is used. (4) Parentheses are used to explain the movements and situation of the speaker in theatrical works. The findings from the samples revealed that the activities in the textbooks gave direct information about certain grammar acquisitions.

However, the following statement is included in the explanation of the curriculum: "... Educational programs that will serve to educate individuals are prepared in a simple and understandable way that takes into account the individual differences rather than a just a way that conveys knowledge only." However, the activities in the textbooks contradict this statement.

\subsection{Findings on the Third Sub-Problem}

The findings on the third sub-problem of the research are discussed below.

Primary school teachers were asked 12 open-ended questions about how grammar acquisition in the curriculum was taught. Also, their opinions on the teaching-learning processes were gathered. The following questions were asked to measure the teachers' opinions:

1. How do you teach reading by paying attention to punctuation marks?

2. How do you teach antonyms?

4. How do you teach writing meaningful and regular sentences?

5. How do you teach the correct use of capital letters and punctuation marks?

6 . How do you teach synonyms?

7. How do you teach the use of interrogative particles?

8 . How do you teach homonyms?

9. How do you teach literal, figurative, and term words?

10. How do you encourage students to check for ambiguity in their writing?

11. How do you teach conjunctions?

12. How do you teach intensive form?

The findings obtained are presented under two headings as the teaching process of grammar acquisitions in the areas of reading and writing.

\subsubsection{Teaching Process for Grammar Acquisition in the Learning Area of Reading}

The participants were asked how they teach "reading by paying attention to punctuation marks and stress, intonation, and pronunciation." Most of the teachers said they impart information about punctuation marks first, and then teach reading by paying attention to punctuation marks by providing a sample text.

I get the students to read stories by giving them information about what punctuation is, its features, and where and how to use it. By enabling students to practice those stories, we find the places where they made mistakes together and read again according to the signs. (T2)

Teachers stated that they generally perform sample readings in response to teaching reading by paying attention to stress, intonation, and pronunciation. They stated that they teach this through games and acting and by performing a 
sample reading and giving information, as presented in the following statement:

I read the text or poem myself first. After reading, I ask the students which words I stress, where my voice tone changes. Then, I make students read the same way I do. (T10)

The area of reading includes the acquisition of "guessing/finding the antonyms of words" from the first to the fourth grade. Teachers were asked how they taught this.

I use sample texts that contain antonyms. I expect the children to feel the words in the texts. I use the concept of "opposite" to make them feel the antonym. I use examples that children see in their daily lives and can be perceptibly understood. (T5)

Teachers reported teaching antonyms using concepts, elements related to daily life, drama, visual materials, brainstorming, and songs. One teacher stated that they also taught this acquisition through activities in textbooks.

Teachers referred to the concept of "feeling" in the teaching process for the first time in the context of this acquisition. This may be because the subject can be presented with more than just conceptual information, as it can be concretized and associated with daily life.

\subsubsection{Teaching Process for Grammar Acquisition in the Learning Area of Writing}

The primary school teachers were asked questions about grammar acquisition in the areas of learning and writing in the curriculum. Their opinions on the process of learning-teaching how to write meaningful and regular sentences to students at the first- and second-grade level were collected. One opinion was as follows:

I ask if the sentence they read has an action, and I try to find out what inferences they make from the sentence. Again, I explain the regular sentence by focusing on the word with action. (T3)

Most of the teachers stated that they drew comparisons with meaningless and ungrammatical sentences to lead the students to write meaningful and regular sentences. They taught through the concept of action and conducted using reading and dictation activities. Although the teachers stated that they helped students find the word with action, there was no explanation for the concept of action in the curriculum. It was determined that teaching is often performed through examples. The teachers also stated that they benefited from the activities about giving examples in the textbooks.

The acquisition of "using capital letters and punctuation marks appropriately" is also included at the fourth-grade level. Only which punctuation marks are taught differs by grade level. One classroom teacher's opinion on how they teach this acquisition is as follows:

I explain the usage areas and the importance of punctuation marks in the story I read. I create samples for each punctuation mark, and I want them to write a sample sentence. I make them find true and false answers to the story. Their learning is reinforced by putting the appropriate punctuation mark in different activities. (T2)

Most of the teachers stated that they use the activities in the textbooks to ensure the correct use of capital letters and punctuation marks. Only one teacher reported that the number of activities in the textbooks was insufficient. The teachers also expressed that they teach through dramatization, textual teaching, and exemplification. Some teachers also stated that they use grammar books.

The curriculum includes the acquisition of "guessing/finding the synonyms of words" in all grades starting from the second grade. One teacher's opinion on the learning-teaching process for this acquisition is as follows:

Synonyms, I give concrete examples based on the same concepts. I use materials. Sometimes I prepare a short video. I give examples after making them feel that synonym means having the same meaning. I ask the children to provide similar examples. I make them write sentences and ask them to find synonyms in the texts. I try to increase the permanence by making them repeat. (T5)

Teachers mostly teach what synonyms are through the meaning of the concept. They also reported teaching in context by using texts. They also stated that they teach through sampling, gamification, and activities in textbooks.

In the curriculum, the acquisition of "writing the interrogative particle according to the rule" is included only in the second grade. One teacher's view on learning-teaching process this acquisition is presented below:

I want them to feel the difference between a positive sentence and an interrogative sentence by making a comparison. I let them find and notice the particle that makes the positive sentence an interrogative sentence. Then, I specify the interrogative particles. I get them to write sample sentences. I want them to write sentences containing an interrogative particle. I check them and give the necessary feedback. (T5) 
Most teachers reported that the interrogative particle should be taught separately through gamification and drama while asking the students to compose an interrogative sentence. However, it was determined from the responses that the students distinguish interrogative sentences from other sentences with the help of the teachers, who use comparisons, examples, and implications.

In the third grade, there is an acquisition on homonyms. The teachers were asked how they teach homonyms in relation to this acquisition. One teacher's view was:

I tried to give them several examples to make them find the words they use in their daily lives. I make them find the words of week's topic. (T2)

Teachers reported generally teaching homonyms based on the context of the text. They also stated that they use visual materials to teach the subject, provide examples, and benefit from the activities in the textbooks.

The acquisition of "determining literal, figurative, and term meaningful words in the text she/he reads" is included in the fourth grade. An example of a teacher's opinion on how they teach the literal, figurative, and term meaning of words is presented below:

I explain what literal, figurative, and term meaningful concepts mean, and I present samples from the texts. After realizing that the concepts are understood by the students, I reinforce the topic with sample texts. (T8)

All teachers stated that to teach this subject, they first impart information about the concepts, and then teach by providing different examples in the context of text using different text types such as narrative and informative texts. The responses revealed that teachers resort to explanations because the concepts are abstract.

The curriculum includes the following acquisition at the fourth-grade level: "T.4.4.11. He/she organizes what he/she writes. ... Students are encouraged to check their writing for ambiguity." The teachers were asked how they teach this acquisition. One teacher's view on this acquisition is presented below:

It may be expressed whether two synonyms as ambiguity are in the same sentence. However, although it is an open-ended statement, this should not be on the teacher's initiative, it should be expressed more clearly and understandably, and appropriate studies should be encouraged. (T7)

The findings of the study revealed that most teachers guide the students in this acquisition. Because teachers think that this acquisition is not suitable for the students' levels. They stated that it was difficult for students to obtain this acquisition independently.

At the fourth-grade level, the curriculum includes the acquisition of "T.4.4.18. Using conjunctions in his/her writings according to the rules." One teacher's view about learning-teaching process this acquisition was:

Whenever I speak, that is, every time I encounter the conjunctions during the lessons, I emphasize that they take a breath for a second and then say it during the conversation. I always state that these should be written separately while writing. While teaching, I make them underline the conjunctions in the texts with a colored pencil. (T1)

Most teachers reported teaching grammar rules on conjunctions through their meaning in a sentence. Some teachers reported providing information about conjunctions directly, while others reported teaching through activities in the textbooks.

The teachers were asked how they taught the acquisition for the correct spelling of intensified words at the fourth-grade level. One teacher's view on this question is given below:

First, I would like to ask what kind of difference there is by giving meaningful words that they use more in life and their intensive forms. I ask them about the meaning and effect they add to the sentence and I want them to increase the number of the examples. (T7)

All teachers reported teaching the intensive form through the meaning they add to a sentence. One teacher stated that they also taught through games, and another stated that they taught through activities in the textbook. Providing direct information in the textbook activities will cause the teaching process to not be performed in accordance with the purpose of the curriculum.

\section{Discussion}

Teaching grammar is aimed at helping the individual communicate properly, develop comprehension and expression skills, and perform mental activities in a healthy way. What needs to be discussed in this context is language teaching methods appropriate for the age of the student. Individuals learn the language within the framework of the grammatical 
rules, whether at home or in a school environment (Aydın, 2009). Therefore, the Turkish language curriculum needs to be prepared in a more detailed way. The aim of teaching language rules is to help learners comprehend the functional features of their language and to ensure its correct use (Karakuş, 2006). From this perspective, the aim of teaching grammar is to make the learning intuitive and the mother tongue clear (Tompkins, 1998, as cited in Ömeroğlu, 2018).

In the 2018 primary school Turkish language curriculum, the main claim made to avoid providing language-related rules and knowledge transfer is that first- and fourth-grade students are in a concrete operational stage, and abstract language rules should not be given to students at this stage. However, the study of Ayranc1 (2018) on language development revealed that children comprehend many abstract language structures, even before the primary school period. This shows that it is not the right decision to exclude students who are at the concrete operational stage in primary school from information about the language. This conclusion leads to the idea that it is appropriate to incorporate language rules and transfer them to students using appropriate approaches and methods.

Punctuation marks are a topic that the curriculum attempts to teach. However, the studies of Erdem (2008), Erdem and Başaran (2010), and Arıc1 (2005) revealed that there were punctuation marks in grammar activities that students had difficulty comprehending. It is contradictory that the punctuation marks that have been taught for four years are among the topics that are difficult to learn. Teaching grammar helps with Turkish language use (Demirel, 2002).

Nevertheless, the fact that different grammatical concepts should first be known for punctuation marks to be taught is not reflected in the curriculum. Grammar education in primary school is an important contribution because the development of students' language skills and competencies is a prerequisite for learning in all other areas, personal and social development, and acquiring professional skills (Aydın \& Sadioğlu, 2018).

Teachers will encounter problems applying textbooks due to the existence of information-based activities in textbooks that have been dealt with by the second sub-problem. Teachers' attempts to teach the acquisitions through textbooks that do not match the language of the curriculum will make the students face the language rules without the necessary foundation.

In addition, the intensive use of different teaching methods and the uncertainty of the reasons for using these methods are also a problem that must be examined. According to the opinions of the teachers, the acquisitions should be expressed more clearly. If the subject frames and the approaches to teaching grammar are determined according to the grade levels, the mother tongue teaching process can be smoother.

As a result, the 2018 Turkish language course curriculum uses a language that diverges from pure knowledge, and although the acquisitions are determined according to grade level, they do not have boundaries, which causes inconsistencies in grammar teaching. The fact that the teaching approaches to be adopted in grammar teaching in the program are not clearly expressed causes teachers to lack guidance in terms of methodology during the teaching process. In addition, the prepared textbooks do not match the program.

\section{Conclusion and Recommendations}

This study aimed to reveal activities presented in textbooks, teachers' opinions on how the learning-teaching process takes place, and the grade level of the grammar acquisitions included in the curriculum within the framework of teaching a mother tongue in the 2018 primary school Turkish language course curriculum. The following data were obtained for each sub-problem of this study.

In the first sub-problem of the study, the researchers examined grammar acquisition in the 2018 primary school Turkish language course curriculum according to the learning areas of reading and writing from first- to fourth-grade level. The amount of grammar taught increases as grade levels increase, as indicated in the curriculum. The findings show that the grammar acquisitions in the curriculum were mostly focused on punctuation marks, stress, intonation, and pronunciation.

The second sub-problem of the study was whether the activities in the primary school Turkish language textbooks match the grammar acquisitions in the 2018 primary school Turkish language course curriculum. The activities in the Turkish textbooks provided direct definitions of grammar rules. The study revealed that this direct information was mostly about the functions of punctuation marks. Contrary to the curriculum, language teaching based on pure knowledge transfer was performed using the textbook activities. This shows that there is a mismatch between the purpose of the curriculum and the preparation of the textbooks.

Finally, the study examined the opinions of primary school teachers on the learning-teaching process of Turkish grammar acquisition. The teachers stated that they provide direct definitions for many subjects that they cannot 
incorporate when teaching the grammar acquisitions and that they try to support these definitions with examples. In addition, the teachers considered the subject of ambiguity as too abstract for primary school students and therefore not suitable. They stated that the framework for the acquisition, especially regarding ambiguity, is not clearly explained; therefore, the teaching of this rule is left to the teacher's initiative. Based on the study findings, the following implications are proposed:

- The curriculum can serve a guide for teachers by including popular approaches to language teaching in the teaching-learning process.

- The question of how to teach grammar rules in mother tongue should be clearly answered in the curriculum.

- Turkish language textbooks should be prepared in accordance with the language teaching process so that the activities in the textbooks used frequently throughout the teaching process do not conflict with the curriculum.

- The importance of a mother tongue should be included in the acquisitions in the curriculum.

\section{References}

Akyol, H., \& Şahin, A. (2019). Teaching Grammar and Spelling. In Hayati Akyol \& Ayfer Şahin (Ed.), Turkish Teaching For Teacher Candidates and Teachers. Ankara: Pegem Academy.

Arıc1, A. F. (2005). Teachers' views on grammar teaching in primary schools. Atatürk University Journal of Kazım Karabekir Education Faculty, 12, 52-60.

Aydın, E. (2013). Czech Republic Czech language and literature basic education program. In Havva Yaman (Ed.), Mother tongue teaching-program reviews in the world. Ankara: Pegem Academy.

Aydın, Ö. (1999). Mother tongue teaching-program reviews in the world. Tömer Language Journal, 81, 23-29.

Aydın, İ. (2009). Activity areas and grammar of the mother tongue lesson. National Education, 37(181), 20-52.

Aydın, Y., \& Sadioğlu, Ö. (2018). Grammar and Orthography in Elementary School Turkish Curricula from the Foundation of the Republic to the Present Day (1923-2017). Journal of Mother Tongue Education, 6(4), 1091-1111. https://doi.org/10.16916/aded.452859

Ayranc1, B. B. (2018). 0-12 Years Language Development Applications and Implementation Requirements. Kirlkkale University Journal of Social Sciences, 8(1), 13-14.

Aytaş, G., \& Çeçen, M. A. (2010). The Place and Importance of Grammar Teaching in Mother Tongue Education. TUBAR-XXVII, 77-89.

Bentolila, A. (2006). Rapport de Mission sur l'enseignement de la Grammaire. Université Paris 5 - Sorbonne.

Büyüköztürk, Ş., Kılıç Çakmak, E., Akgüm, Ö. E., Karadeniz, Ş., \& Demirel, F. (2012). Scientific research methods. Ankara: Pegem Academy.

Can, T. (2009). Learning and teaching languages online: A constructivist approach. Novitas-Royal, 3(1).

Cemiloğlu, M. (2001). Turkish teaching in primary schools. İstanbul: Alfa.

Cemiloğlu, M. (2004). Turkish teaching in primary schools (4th ed.). İstanbul: Aktüel.

Christensen, L. B., Johnson, R. B., \& Turner, L. A. (2015). Research methods, design and analysis. Ankara: An1.

Demir, C., \& Yapıc1, M. (2007). Turkish Teaching as a Special Teaching Field and its Problemsı. Journal of Social Sciences, $I X(2), 177-192$.

Demirel, Ö. (2000). Turkish Teaching. (2nd ed.). İstanbul: Pegem Academy.

Demirel, Ö. (2002). Turkish Teaching. Ankara: Pegem Academy.

Dolunay, S. K. (2009). Teaching of the tense suffixes and their functions at the second level of primary education, (Unpublished master thesis). Gazi University, Institute of Education Sciences, Ankara, Turkey.

Erdem, İ. (2007). A Research on the problem of teaching grammar in the secondary schools, (Unpublished master thesis). Gazi University, Institute of Education Sciences, Ankara, Turkey.

Erdem, İ. (2008). Difficulties in teaching grammar subjects according to teachers' views. Turkish Journal of Educational Sciences, 6(1), 85-105.

Erdem, İ., \& Başaran, M. (2010). The Influence of the Teachers' Grammar View from the Schools They Graduated 
on Their Grammar Understanding. TÜBAR-XXVII, 321-339.

Göğüş, B. (1978). Turkish and literary education in our secondary schools. Ankara: Gül.

Güneş, F. (2007). Turkish teaching and mental structuring. Ankara: Nobel.

Güneş, F. (2013). New Approaches in Teaching Grammar. Journal of Language and Literature Education, 2(7), 71-92. https://doi.org/10.12973/jlle.11.206

Güven, A. Z. (2013). Problems of Teaching Linguistics Subjects. Journal of Language and Literature Education, 2(6), 1-10.

Primary school Turkish textbook 1st grade (2019). Ankara: Cem Web Offset A.Ş.

Primary school Turkish textbook 1st grade (2019). Ankara: Ministry of National Education.

Primary school Turkish textbook 2nd grade (2019). Ankara: Koza.

Primary school Turkish textbook 3rd grade (2019). Ankara: Ministry of National Education.

Primary school Turkish textbook 3rd grade (2019). Ankara: Sonuç.

Primary school Turkish textbook 4th grade (2019). Ankara: Ministry of National Education.

Primary school Turkish textbook 4th grade (2019). Ankara: Koza.

Imla Kılavuzu (2000). Ankara: Türk Dil Kurumu.

İşcan, A. (2015). Diction, phonics and vocal training. In Abdullah İşcan (Ed.), Speech training methods and activities. Ankara: Pegem Academy.

İşcan, A., \& Kolukısa, H. (2005). Situation, problems and solution suggestions of primary education second grade grammar teaching. Atatürk University, Journal of the Institute of Social Sciences, 5(1), 299-308.

Kantaş, Z. (2013). German primary education German curriculum (2004-2005). Havva Yaman (Ed.), Mother tongue teaching-program reviews in the world. Ankara: Pegem Academy.

Karakuş, İ. (2006). Turkish teaching in the Atatürk period education system. Ankara: Türk Dil Kurumu.

Kavcar, C., Oğuzkan, F., \& Sever, S. (1997). Turkish teaching. Ankara: Engin.

Korkmaz, Z. (1992). Dictionary of grammar terms. Ankara: Türk Dil Kurumu.

MEB, (2018). Turkish course curriculum. Ankara: Ministry of National Education.

Merriam, S. B. (2018). Qualitative research: a guide to design and practice. Ankara: Nobel.

Ömeroğlu, A. F. (2018). An Investigation of Grammar Teaching in terms of the Turkish Language Course Curricula between the Years 2004-2017. Journal of Mother Tongue Education, 6(1), 260-280.

Öz, M. F. (2001). Applied Turkish teaching. İstanbul: An1.

Öz, M. F. (2006). Applied Turkish teaching. Ankara: Anı.

Özbay, M. (2006a). Turkish special teaching methods II. Ankara: Öncü Bookstore.

Sever, S. (2000). Turkish teaching and full learning (3rd ed.). Ankara: An1.

Schulze, M. (1998). Checking grammar-teaching grammar. Computer-assisted language learning, 11(2), $215-227$. https://doi.org/10.1076/call.11.2.215.5691

Seggie, F. N., \& Bayyurt, Y. (2017). Qualitative research methods, techniques, analysis and approaches. Ankara: An1.

Sinanoğlu, S. (1958). The importance of grammar. Türk Dili, 7(81), 438-440.

Tusting, K., \& Barton, D. (2011). A Brief Review of Learning Theories and Adult Learning Models. (Translated by Ahmet Yildiz \& Aylin Demirli). Ankara: Dipnot.

Ünalan, Ş. (2006). Turkish teaching (3rd ed.). Ankara: Nobel.

Ünal, E., \& Şahinci, C. (2011). The ınvestıgatıon of Turkısh language teacher's opınıns about the teachıng of sixth, seventh and eighth grade primary educatıon Turkısh grammer. Turkish studies-international periodical for the languages, literature and history of Turkish or Turkic, 6(1), 1849-1862.

Yaman, H., \& Demirtaş, T. (2013). Main features of mother tongue teaching programs. In Havva YAMAN (Ed.), 
Mother tongue teaching-program reviews in the world. Ankara: Pegem Academy.

Yıldırım, A., \& Şimşek, H. (2018). Qualitative research methods in the social sciences. Ankara: Seçkin.

Y1ldz, C. (2003). Alternative methods in Turkish teaching. Ankara: Anı.

\section{Copyrights}

Copyright for this article is retained by the author(s), with first publication rights granted to the journal.

This is an open-access article distributed under the terms and conditions of the Creative Commons Attribution license (http://creativecommons.org/licenses/by/4.0/). 